\title{
Trade Facilitation and the EU-ACP Economic Partnership Agreements
}

\author{
Maria Persson \\ Lund University
}

\begin{abstract}
This paper assesses the potential effects from trade facilitation in terms of increased trade flows both on average and specifically for the six regional groups of ACP countries negotiating Economic Partnership Agreements (EPAs) with the EU. Data from the World Bank's Doing Business Database on the time required to export or import are used as indicators of cross-border transaction costs, and a gravity model on two-way bilateral trade between 22 EU countries and 100 developing countries is estimated using a sample selection approach. The results suggest that time delays on the part of the exporter and the importer generally significantly decrease trade flows, but also that this effect is not constant, in the sense that the elasticity of trade with respect to border delays declines at higher levels of time requirements. On average, lowering border delays in the exporting country by one day from the sample mean would yield an export-increasing effect of about 1 percent, while the same reduction in the importing country would increase imports by about 0.5 percent. Significant negative effects are also found of both export and import transaction costs for most EPA groups, and the effects tend to be at least as large as the average or larger. The results are generally robust for a number of alternative estimation methods such as Poisson estimation, IV estimation taking sample selection into account and the sample selection approach suggested by Helpman et al. (2007).
\end{abstract}

- JEL classification: C21, F15, O24

- Key words: trade facilitation, EU, ACP, economic partnership agreements, gravity model, sample selection

\footnotetext{
*Corresponding address: Lund University, Department of Economics, P.O. Box 7082, SE-220 07 Lund, Sweden; Tel: +46 46 2224670, Fax: +46 46 2224613, E-mail: maria.persson@nek.lu.se.

(2008-Center for International Economics, Sejong Institution, All Rights Reserved.
} 


\section{Introduction}

The subject of trade facilitation, i.e. loosely speaking, measures to lower transaction costs related to cross-border trade procedures, has emerged as an important issue in the current trade policy debate. This increased focus is no doubt related to the fact that many tariff and non-tariff barriers have been reduced or eliminated in the past rounds of multilateral trade negotiations, thus increasing the relative costs of inefficient trade procedures. It is perhaps also an easier subject to tackle than some other imminent questions, considering that no country gains in any obvious sense from having burdensome procedures. In the words of the European Union (EU) Trade Commissioner Peter Mandelson: "there are no losers from trade facilitation reform, only winners".

In the World Trade Organization (WTO), trade facilitation is one of the four socalled Singapore issues, ${ }^{2}$ all of which at one stage were supposed to be included in the Doha Development Agenda, but where trade facilitation now is the only one remaining. ${ }^{3}$ Negotiations on trade facilitation in the Doha Round have been successful, but the general breakdown of negotiations in the summer of 2006 made several countries increase their attention to regional trade agreements and negotiations. In the context of the EU's trade relations with developing countries, much of the focus was transferred to the ongoing negotiations for creating Economic Partnership Agreements (EPAs) with six regional groups according to the Cotonou Agreement's pledge to replace the current non-reciprocal and non-WTO compatible preferences for African, Caribbean and Pacific (ACP) countries. Besides covering, among other things, issues of tariff and non-tariff barriers to trade, these negotiations are supposed to address all Singapore issues.

This paper has a twofold objective. Firstly, we want to assess how export and import transaction costs related to cross-border trade procedures affect trade flows on average, or, in other words, if there are potential trade effects from trade facilitation in general. Secondly, we also want to decompose these effects to see the specific

\footnotetext{
${ }^{1}$ See Nath and Mandelson (2006). Obviously, this is not strictly true, since some parties, such as customs officials, might lose from the inability to demand bribes, or from losing their jobs due to more efficient cross-border procedures. From a country welfare perspective though, one does indeed expect gains.
}

${ }^{2}$ The others being trade and investment, competition policy and transparency in government procurements.

${ }^{3}$ For an overview of the work going on in the WTO and in the negotiations, see WTO (2006). 
potential for each EPA negotiating group as well as for the EU. ${ }^{4}$ To this end, we use data from the World Bank's (2007) Doing Business Database on the time required to export or import as indicators of trade transaction costs. We estimate a gravity model on two-way bilateral trade between $22 \mathrm{EU}$ countries and 100 developing countries using a sample selection approach.

To the best of our knowledge, the potential trade effects of trade facilitation on EPA groups have not been estimated before. Besides looking at a new question, one of the main contributions of this paper, compared with other papers in the general area of trade facilitation, is that it uses a less restrictive model, allowing trade facilitation in both the exporting and the importing country to affect bilateral trade flows, as well as allowing the effect of trade facilitation to be non-linear. ${ }^{5}$ Further, it takes recent methodological developments into account and, in addition to the main alternative of Heckman estimation, confirms the results using a Poisson Pseudo-Maximum-Likelihood estimator, instrumental variables estimation corrected for sample selection, and a new sample selection approach suggested by Helpman et al. (2007). The data on the time requirements for exports have been used before, but not the data on border delays in the importing country.

To summarize our results, we find that time delays on the part of both the exporter and the importer, proxying export and import transaction costs, generally significantly decrease trade flows. We also find that the elasticity is not constant: waiting a little longer has smaller marginal effects if the time requirements are already high. On average, lowering border delays in the exporting country by one day from the sample mean would yield an export increasing effect of about 1 percent, while the same reduction in the importing country would increase imports by about 0.5 percent. We also find significant negative effects of export and import transaction costs for most, though not all, EPA groups and the EU, with the effects being at least as large as the average, or larger.

\footnotetext{
${ }^{4}$ Trade facilitation could affect a country's economy through several links, such as trade flows, flows of foreign direct investment (FDI) or government revenue through the collection of trade taxes. In this paper, we only assess the effects on trade flows. For a discussion of these possible links, as well as an overview of studies, see Engman (2005).

${ }^{5}$ Or more precisely: allowing the elasticity of trade with respect to transaction costs to be non-constant so that additional costs will have smaller marginal effects if the level of cost is already high.
} 


\section{Background}

\section{A. Trade Facilitation Defined}

Despite the recent years' increased attention to trade facilitation, there is no real consensus on how the term should be defined. Generally, there are at least two broad ways of looking at the issue: either to use a narrow focus on what has been called at the border procedures, or to use a wider perspective and also include so-called behind the border measures.

One common way to narrowly define trade facilitation originates with the WTO, and is e.g. used by Engman (2005), stating that trade facilitation is "the simplification and harmonization of international trade procedures", where international trade procedures are the "activities, practices and formalities involved in collecting, presenting, communicating and processing data required for the movement of goods in international trade". This definition clearly limits the attention to what happens around the border.

With a slightly less narrow definition, the Doha Ministerial Declaration (WTO 2001) refers to trade facilitation as "expediting the movement, release and clearance of goods, including goods in transit". This leaves some room for looking at, for instance, transport infrastructure. ${ }^{6}$

Defining trade facilitation even more broadly, Wilson et al. (2003; 2005) include both direct border elements such as port efficiency and customs administration, and some working more behind the border, such as domestic regulatory environment and services infrastructure.

A nice summing up of the various ways to look at the matter is given by Roy and Bagai (2005), who say that "trade facilitation [...] aims to make trade procedures as efficient as possible through the simplification and harmonization of documentation, procedures and information flows." They add that

In a narrow sense, it addresses the logistics of moving goods through ports or customs. More broadly, it encompasses several inter-related factors such as customs and border agencies, transport infrastructure (roads, ports, airports etc.), services and information technology (as it relates to better logistics), regulatory

${ }^{6}$ Note that the negotiations in the WTO are supposed to cover GATT article V (freedom of transit), article VIII (fees and formalities connected with importation and exportation) and article $\mathrm{X}$ (publication and administration of trade regulations); see WTO (2006). 
environment, product standards, Technical Barriers to Trade [...] etc. in order to lower [the] cost of moving goods between destinations and across international borders. $^{7}$

In this study we choose to work with the same kind of narrow perspective on trade facilitation as used by Engman (2005). Borrowing a line from Roy and Bagai (2005), our definition might be summarized as measures to decrease the transaction costs arising from the "moving [of] goods through ports or customs".

\section{B. Economic Partnership Agreements}

Relations between the EU and ACP countries began to change with the signing of the Cotonou Agreement in June 2000. This agreement stipulates that the nonreciprocal trade preferences previously applying to EU-ACP trade only should remain in place until December 31, 2007, at the latest. On this date, new WTOcompatible trade arrangements - Economic Partnership Agreements (EPAs) - are scheduled to enter into force. ${ }^{8}$

Negotiations on the terms of the envisioned EPAs have been underway since September 2002. The first phase took place at an all-ACP-EU level and addressed general issues of interest to all parties. A second phase of negotiations, launched in 2003-2004, is being held at a regional level, where six groupings of ACP countries negotiate separately with the EU. These regional negotiating groups are found in Table 1, with least developed countries (LDCs) in italics.

Trade facilitation was not explicitly mentioned in the Cotonou Agreement, but other documents from both sides clearly suggest that it is seen by most parties as an issue to be included in the EPA negotiations, see e.g. European Commission (2002, 2007a) and ACP Council of Ministers (2002). At this point, trade facilitation is de facto explicitly an issue in all six EPA negotiations. ${ }^{9}$

Given that parties in the ongoing EPA negotiations are dealing with the issue of

\footnotetext{
${ }^{7}$ Trade facilitation is clearly linked to the broader issue of Non-Tariff Barriers to Trade (NTBs), but the latter includes many more obstacles to trade. Even more generally, trade facilitation belongs to the literature on trade costs - for an overview see Anderson and van Wincoop (2004).

${ }^{8}$ Since the existing preferences do not apply to all developing countries, they are not covered by the Enabling Clause, and hence have to operate under a WTO-waiver. For the new preferences to be WTOcompatible, they would have to be reciprocal. For a description of ACP preferences since the 1960s and an estimation of their effects, see Persson and Wilhelmsson (2007).

${ }^{9}$ For an overview of trade facilitation in these negotiations, see Nyamache (2006).
} 
Table 1. EPA Negotiating Groups

\begin{tabular}{ll}
\hline \multicolumn{1}{c}{ EPA Grouping } & \multicolumn{1}{c}{ Countries } \\
\hline West Africa & $\begin{array}{l}\text { Benin, Burkina Faso, Cape Verde, Côte d'Ivoire, Gambia, Ghana, Guinea, } \\
\text { Guinea-Bissau, Liberia, Mali, Mauritania, Niger, Nigeria, Senegal, Sierra } \\
\text { Leone, Togo }\end{array}$ \\
Central Africa & $\begin{array}{l}\text { Cameroon, Central African Republic, Chad, Congo Dem. Rep., Congo } \\
\text { Rep., Equatorial Guinea, Gabon, São Tomé and Principe }\end{array}$ \\
Eastern and & Burundi, Comoros, Djibouti, Eritrea, Ethiopia, Kenya, Madagascar, Malawi, \\
Southern Africa & Mauritius, Rwanda, Seychelles, Sudan, Uganda, Zambia, Zimbabwe \\
SADC & Angola, Botswana, Lesotho, Mozambique, Namibia, (South Africa), \\
(Southern Africa) & Swaziland, Tanzania \\
Caribbean & Antigua and Barbuda, Bahamas, Barbados, Belize, Dominica, Dominican \\
& Republic, Grenada, Guyana, Haiti, Jamaica, St. Kitts and Nevis, St. Lucia, \\
& St. Vincent and the Grenadines, Suriname, Trinidad and Tobago \\
Pacific & Cook Islands, Fiji, Kiribati, Marshall Islands, Micronesia, Nauru, Niue, Palau, \\
& Papua New Guinea, Samoa, Solomon Islands, Tonga, Tuvalu, Vanuatu
\end{tabular}

Note: East Timor does not participate in any EPA negotiations. Cape Verde announced in September 2006 that it was leaving the West African EPA configuration (ECDPM 2006). Congo Dem. Rep. was first a part of the negotiating group for Eastern and Southern Africa (ESA), but switched to the Central African group at the end of 2005. South Africa started as an observer in the SADC EPA group, but has now become a negotiating party (European Commission 2007b). Least developed countries in italics.

trade facilitation, at the same time as a large number of other questions, there is clearly a need to assess just how important trade facilitation is. If there is no clear evidence suggesting economic gains, scarce negotiation and implementation resources could be better allocated elsewhere. If, however, there are large potential gains, this motivates a focus on trade facilitation. In this paper, we contribute with a first step in this assessment, by estimating how the cross-border trade costs that trade facilitation is meant to lower affect trade flows.

\section{Previous Studies}

There is a growing literature on the effects of trade facilitation, but, to the best of our knowledge, no previous study has looked at this issue in the context of the EU's relations with ACP countries. However, there are several studies that primarily use either a gravity approach or a Computable General Equilibrium (CGE) model to quantify the effects of trade facilitation in general or in some other specific context.

Using various data sources and estimation methods, papers in the gravity tradition have tended to find significant effects. Wilson et al. $(2003 ; 2005)$ include four separate trade facilitation indicators in a gravity model estimated with OLS. 
All trade facilitation indicators are significant in most regressions, but it is noteworthy that their indicator for customs environment, i.e. the indicator that most closely resembles our indicators for potential trade facilitation, is only included for the importing country. ${ }^{10}$ Soloaga et al. (2006) use the same methodology and type of data, but estimate the gravity model with a negative binomial regression. Unlike Wilson et al., they include customs efficiency for both the exporter and the importer. ${ }^{11}$

Djankov et al. (2006) use an earlier version of the same data as this paper to estimate how time delays affect exports, using a difference gravity equation estimated for similar exporters. Looking only at delays in the exporting country, their main result is that, on average, for each additional day that a product is delayed, trade is reduced by at least 1 percent. Also in the gravity tradition, Nordås et al. (2006) use a Heckman selection process to see how time delays affect both the size of observed trade flows and the probability that trade between two countries will occur. Studying exports from 192 countries to Australia, Japan and the United Kingdom, the authors find that the time needed to export in most cases have a negative impact on the probability to export and the exported volumes.

Apart from these gravity studies, there are also some that use CGE models to simulate the effects of trade facilitation: examples include OECD (2003), Francois et al. (2005), The Swedish National Board of Trade (2006), Decreux and Fontagné (2006), Hertel and Keeney (2006) and Dennis (2006). Generally, these papers find substantial gains from trade facilitation, and, interestingly, effects tend to be larger for developing countries.

In addition to these CGE studies, Hummels (2001) estimates how much long transport times reduce the probability that the US will import from a particular country, and how much value may be saved by decreasing the number of shipping days.

\section{Methodology}

\section{A. Model and Estimation Issues}

To answer the question of how cumbersome cross-border trade procedures affect

\footnotetext{
${ }^{10}$ Note also that the underlying data are not available for many developing countries, especially in SubSaharan Africa - this is one major reason why we do not use the same data.

${ }^{11}$ Puzzlingly, although they find the expected positive and significant effect from customs efficiency in the exporting country, the corresponding coefficient is robustly negative and significant for the importing country.
} 
trade flows both generally, and specifically for the EPA groups and the EU, we estimate a gravity equation including measures for export and import transaction costs. The model is estimated on two-way import flows between EU countries and developing countries.

The gravity equation has been widely used to estimate the effects of e.g. preferential trading arrangements and various trade costs, but has also at times been criticized for lacking a solid theoretical basis. There is, however, a growing consensus that this is not the case, and among the papers often cited are Anderson (1979), Bergstrand (1985; 1989), Helpman and Krugman (1985) and Deardorff (1998). We choose to use a model originating with Anderson and van Wincoop (2003), who derive the gravity model using assumptions of constant elasticity of consumption (CES) preferences and goods being differentiated by place of origin. They assume unitary income elasticities, and include so-called multilateral resistance terms. ${ }^{12}$

In its original multiplicative form, the baseline model used is:

$$
\begin{aligned}
M_{i j} & =e^{\alpha_{0}}\left(Y_{i} Y_{j}\right)^{\alpha_{1}} D_{i j}^{\alpha_{2}} X_{i j}^{\beta} Z_{i}^{\gamma} W_{j}^{\varphi} \text { region }_{i}^{\lambda} \text { region }_{j}^{\mu} T F I_{i}^{\delta_{1}} T F E_{j}^{\phi_{1}} \\
& * \exp \left[\theta_{1}\left(\ln T F I_{i}\right)^{2}+\theta_{2}\left(\ln T F E_{j}\right)^{2}\right] e^{\varepsilon_{i j}}
\end{aligned}
$$

where $M_{i j}$ is imports to country $i$ from country $j . Y_{i} Y_{j}$ is the product of the countries' incomes measured as real GDP, and, to be less restrictive than in the original model, income elasticities are allowed to differ from one. Trade flows are modelled to depend on the bilateral distance between the countries' capitals, $D_{i j}$. We include a vector $X_{i j}$ of bilateral variables that might affect trade: dummy variables capturing whether country $i$ and $j$ share a border, the same language, or have ever been in a colonial relationship. Further, there are two vectors of importer $\left(Z_{i}\right)$ and exporter $\left(W_{j}\right)$ specific variables: the latter includes land area, population size and dummies for being landlocked, an LDC or a major oil exporter, while the former, in addition, contains tariff level and a measure of tariff dispersion: for a description of all variables, including data sources, see Table 6 below. ${ }^{13}$ Since the effects of several variables might be expected to differ between developed and developing countries, the coefficients are allowed to be different for developing and EU countries by also adding all variables interacted with an EU dummy. ${ }^{14} \varepsilon_{i j}$ is a disturbance term.

Anderson and van Wincoop (2003) emphasize the importance of controlling for

${ }^{12}$ Capturing the fact that for any given level of bilateral barriers between countries $i$ and $j$, if $i$ has high barriers to its other trade partners, this will reduce the relative price of country $j$ goods, and hence increase imports from $j$. 
multilateral resistance, and suggest that one way of doing this is to include exporter and importer specific effects. Since the available data on export and import transaction costs are country-specific and hence do not vary by trade partner, we cannot include specific effects for every exporting and importing country (these would capture the combined effects of all variables that do not vary by trade partner for a certain exporter or importer and hence we could not measure the separate effect of transaction costs). ${ }^{15}$ We do, however, include region-specific exporter and importer effects. Though not ideal, this should capture to some extent the multilateral resistance effects, as well as effects of heterogeneity more generally, as long as this heterogeneity is common within small regions, but differ between them. Specifically, we add exporter and importer specific dummy variables for every EPA group and likewise for seven different geographical regions - see Table 7 below.

To capture the average potential impact of trade facilitation, there are measures of the degree of export transaction costs in the exporting country $j: T F E_{j}$, and import transaction costs in the importing country $i$ : $T F I_{i}$. These are measured as the number of days needed to export or import a standardized good. The hypothesis is that transaction costs will decrease trade flows whether they occur in the exporting country or at the destination, so we expect these coefficients to be negative. Since the elasticity of trade with respect to delays could be expected to decline at higher levels of costs, i.e. the effects of transaction costs are not necessarily constant, the square of (the log of) these export and import transaction costs are also added to the model. We expect their coefficients to be positive. ${ }^{16}$

To be able to estimate the specific effect that trade transaction costs have in each EPA group and in the EU, the model is also extended by including interaction

\footnotetext{
${ }^{13}$ Most of these variables are quite standard and are meant to capture various forms of trade costs (such as being landlocked) or lack thereof (such as sharing the same language). Land area is not always used, but is included here as a proxy for infrastructure: particularly for developing countries, a large land area can be expected to be associated with higher transportation costs. Population is included to allow for the possibility of non-homothetic preferences. The inclusion of a dummy for oil exporters is motivated by the fact that the dependent variable is total imports. Since oil is a special commodity, not controlling for this in some way would risk leading to incorrect conclusions - however, the results do remain very similar even if this dummy is not included.

${ }^{14}$ Regional exporter effects for developing countries by construction capture the EU tariff level, so the tariff variables are only included for developing countries.

${ }^{15}$ In principle, being able to use panel data would remedy this problem. However, even though the data used to measure transaction costs are now available for two more years, there is very little time-series variation, so not much information would be gained by adding more years.
} 
variables, where the variables capturing export and import transaction costs are multiplied with importer and exporter specific EPA and EU dummy variables.

With this addition, the transaction cost variables will enter as $\operatorname{TFI}_{i}{ }^{\delta_{1}+\delta_{2} E U_{i}+\sum_{m=1}^{6}} \delta_{2_{2+m} E A_{i}^{m}}$, and

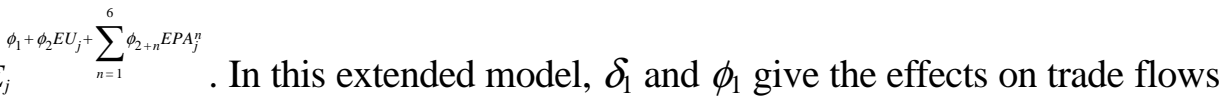
from import and export transaction costs respectively, for the reference group of countries that are not members of the EU or any EPA grouping. To get the effect for EU and EPA countries, the additional effect stemming from transaction costs for these countries, captured by the relevant interaction term coefficients, must be added to this main effect.

To estimate the baseline and extended models, we choose to use a simple sample selection model. As noted by e.g. Helpman et al. (2007), when the log-linear form of the gravity model is estimated with OLS, all country-pairs that have zero trade flows are excluded from the regression, which introduces a bias. One way to solve this problem is to first model a selection process where the probability that a countrypair will trade is estimated using probit estimation, and then use this information in a second step estimation of trade volumes. This is just the standard Heckman procedure for sample selection. Following Helpman et al. (2007), we use data from the World Bank (2007) on the costs and procedures involved in starting a business in various countries as the additional variables included only in the selection equation. The idea is that these variables only affect fixed trade costs, but not variable trade costs, and by only including them in the first stage equation, the second stage trade flow equation may be identified. All other variables are assumed to affect both the probability that trade occurs and trade volumes. ${ }^{17}$

\section{B. Data}

The data used to measure the potential for trade facilitation comes from the

\footnotetext{
${ }^{16}$ Adding the squared term is a simple way to allow the elasticity to vary which works well when estimating the effects for EPA groups. We also, however, explore how the elasticity varies with increasing costs by explicitly allowing different effects for countries with different ranges of time-delays at the border: one effect for countries with delays of 1-20 days, another for those with 21-40 days and so on. We thank an anonymous referee for making this suggestion.

${ }^{17}$ On the basis of a theoretical model - building on the model in Melitz (2003) - that accounts for both firm heterogeneity and fixed trade costs, Helpman et al. (2007) argue that one should not only correct for sample selection, but also for the impact of the fraction of exporting firms. We use their approach for the second correction as a robustness test and find that the results do not differ much.
} 
World Bank (2007) Doing Business Database. In the Trading Across Borders section of the database, local trade professionals have answered a number of survey questions about, among other things, how much time it would take to export or import a certain standardized good. ${ }^{18}$

Transaction costs at border crossings may arise due to a number of reasons, but the time required to export or import a good will likely be a good proxy for all these transaction costs. For instance, having to collect many signatures or fill out many documents might involve direct costs, but it will also increase the time needed to get the good through customs. Port congestion and waiting due to insufficient staffing etc, will also lead to higher time requirements. In turn, as noted by Djankov et al. (2006), long time delays will act as a tax on exports (or imports) as a result of at least three factors: depreciation of the good, resources being allocated to storage and transport instead of other uses, and the fact that long delays are associated with increased uncertainty about delivery times. Therefore, we argue that border delays are not only a good indicator of the customs environment, but more specifically, a good proxy for the transaction costs that trade facilitation is meant to lower. ${ }^{19}$

The data on the number of days needed to export or import the standardized good is available for 155 countries for 2005. Part of the data has been used to measure trade facilitation in Djankov et al. (2006). However, unlike that paper, we use the data over time needed for both exports and imports, corresponding to the

\footnotetext{
${ }^{18}$ To make the data comparable across countries, it is assumed that the hypothetical trading firm is a private limited liability company, fully domestically owned with a minimum of 200 employees; that it is located in the country's most populous city but does not operate within an export processing zone (EPZ) or an industrial estate with special export or import privileges and that it exports more than 10 percent of its sales to international markets. The good is assumed to be non-hazardous, not to include any military arms or equipment, not to require refrigeration or any special environment, not to require any special phytosanitary or environmental safety standards, and to be shipped in a dry-cargo, 20-foot, full container load. The good is further assumed to fall under the categories of "textile yarn, fabrics and made-up articles", "articles of apparel and clothing accessories" or "coffee, tea, cocoa, spices and manufactures thereof". Trade is assumed to take place by ocean transportation through the closest or main port from the most populous city (the port may be located in another city or country). For imports, all procedures from the conclusion of a purchase contract to the arrival of the goods at the importer's warehouse are included, and for exports the process starts with the conclusion of a sales contract and ends with the good leaving the port of exit. For more specifics, see World Bank (2007), or Djankov et al. (2006), both of which offer an excellent review of the data.

${ }^{19}$ As we are working with a relatively narrow definition of trade facilitation, concentrating on what happens at the border, there might be some concern that the time measure picks up too many aspects, i.e. also obstacles behind the border. This should not be a major problem, however, since about 75 percent of the delays in the sample are due to "administrative hurdles" - customs procedures, tax procedures, clearances and cargo inspections (Djankov et al., 2006).
} 
hypothesis that not only what a country does on its own matters, but the situation in its trading partners will also affect bilateral trade flows.

There are some possible concerns with using this data as an indicator of potential trade facilitation. It captures differences between countries in the time it takes a large firm to export or import a relatively time-insensitive good, but if costs arising from delays differ within countries due to the sensitivity of the good and the size of the firm, ${ }^{20}$ this will not be captured. Related to this, for every country, the time needed to export or import is implicitly assumed to be the same for all trading partners. If the composition of trade varies with trading partners, this is not an ideal measure of the transaction costs in a specific bilateral trade flow. ${ }^{21}$ We would argue, however, that the sample that we use reduces the problem. We include bilateral trade flows between EU countries and developing countries, where the composition of trade may be expected to be more even than if we also include trade between developing or industrialized countries. Further, there is likely a high correlation between the time requirements for different kinds of goods, so if border delays for the survey's standardized good are large, this should be a good indicator of a generally inefficient customs environment.

Using the Doing Business Database to measure the potential for trade facilitation gives us a sample of 22 EU countries: Cyprus, Luxembourg and Malta disappear. To get a well-defined sample of developing countries, all countries that were eligible for preferences under the EU's Generalized System of Preferences in 2005 are included. As is the case with the EU, some countries disappear due to missing data - the sample is found in Table 7.

Lastly, it is interesting to look at some descriptive statistics for the measures of potential trade facilitation. While it is hardly surprising that it generally takes more time to import a good than to export it, as is evident from Table 2, there are large differences among country groups. Cross-border trading is particularly timeconsuming in Sub-Saharan Africa, with very long delays in Eastern and Southern Africa (ESA) and Central Africa, while Pacific countries, for instance, are almost as efficient as countries within the EU. However, there are also large differences within country groups. For instance, in ESA, importers only have to wait an average

\footnotetext{
${ }^{20}$ As discussed e.g. in OECD (2003).

${ }^{21}$ Besides that fact that the data apply to three relatively time-insensitive goods, as pointed out by an anonymous referee, it should also be well noted that the data might overstate the time requirements for firms operating within EPZs or for parties having standing orders with each other. Also, bulk cargo (such as grains, minerals etc) or goods that are air freighted might not be well-represented by the data.
} 
Table 2. Days Needed for Exporting and Importing

\begin{tabular}{lcccccc}
\hline & \multicolumn{3}{c}{ Exporting } & \multicolumn{3}{c}{ Importing } \\
\hline Region & Mean & Min & Max & Mean & Min & Max \\
\hline West Africa & 41 & 21 & 69 & 52 & 26 & 89 \\
Central Africa & 53 & 27 & 87 & 63 & 29 & 111 \\
Eastern and Southern Africa & 52 & 16 & 80 & 67 & 16 & 124 \\
SADC & 42 & 30 & 74 & 47 & 25 & 85 \\
Caribbean & 34 & 17 & 58 & 39 & 17 & 60 \\
Pacific & 17 & 11 & 30 & 19 & 8 & 32 \\
European Union & 13 & 3 & 29 & 15 & 5 & 34 \\
Non-EU, Non-ACP & 33 & 13 & 105 & 42 & 13 & 139 \\
Total & 32 & 3 & 105 & 40 & 5 & 139 \\
\hline
\end{tabular}

Note: Author's calculations. Data from the World Bank (2007) Doing Business Database.

of 16 days in Mauritius, while the corresponding delay is 124 days in Burundi.

\section{Empirical Results}

The empirical results of the Heckman estimation of the baseline and extended models can be found in Table $3 .^{22}$ Starting with the baseline model, the average levels of export and import transaction costs both have the expected negative coefficients, and are highly significant. The coefficient for export transaction costs is somewhat larger at -1.5 , with the corresponding coefficient for import transaction costs being about -1.3. Hence, these coefficients are of the same magnitude as the coefficient for distance. Interestingly, the squared trade facilitation variables are also significant and have the expected positive sign. Therefore, it is important to note that the regression coefficients for TFE and TFI are not elasticities, which they normally would be in a gravity model. Due to the significant squared term, the expression for the elasticities will also include the level of transaction costs, so that higher levels of costs are associated with smaller elasticities. In other words, border delays, proxying indirect trade transaction costs, on average have a significant negative effect on trade flows both when they occur in the exporting country and at the destination, but the

\footnotetext{
${ }^{22}$ The models are estimated using STATA's Heckman, twostep command with bootstrapped standard errors. Only actual zeros in the import data are interpreted as zero trade flows, but also interpreting missing import values as zero trade flows does not alter the results. Full results for all variables can be found in Table 8 in the appendix. Coefficients for the usual gravity variables are generally very much in line with what could be expected, and will not be further commented upon.
} 
Table 3. Estimation Results for Export and Import Transaction Costs

\begin{tabular}{|c|c|c|c|c|c|}
\hline & & \multicolumn{2}{|c|}{ Exporting: TFE } & \multicolumn{2}{|c|}{ Importing: TFI } \\
\hline & & Regr. Coeff. & Sum TFE & Regr. Coeff. & Sum TFI \\
\hline \multirow[t]{4}{*}{ Baseline Model } & TF Average All Countries & -1.506 & & -1.267 & \\
\hline & & {$[0.000]^{* * *}$} & & {$[0.002]^{* * *}$} & \\
\hline & $(\operatorname{lnTF})^{2}$ & 0.174 & & 0.147 & \\
\hline & & {$[0.021]^{* *}$} & & {$[0.024]^{* *}$} & \\
\hline \multirow[t]{18}{*}{ Extended Model } & West Africa & -1.029 & -2.865 & -0.583 & -0.586 \\
\hline & & {$[0.036]^{* *}$} & {$[0.000]^{* * *}$} & {$[0.096]^{*}$} & {$[0.500]$} \\
\hline & Central Africa & -0.026 & -1.862 & 0.254 & 0.251 \\
\hline & & {$[0.982]$} & {$[0.175]$} & {$[0.762]$} & {$[0.851]$} \\
\hline & Eastern and Southern Africa & -0.582 & -2.418 & -0.68 & -0.683 \\
\hline & & {$[0.070]^{*}$} & {$[0.001]^{* * *}$} & {$[0.007]^{* * *}$} & [0.407] \\
\hline & SADC & -3.253 & -5.089 & -2.225 & -2.228 \\
\hline & & {$[0.071]^{*}$} & {$[0.008]^{* * *}$} & {$[0.044]^{* *}$} & {$[0.095]^{*}$} \\
\hline & Caribbean & -0.245 & -2.081 & 0.061 & 0.058 \\
\hline & & {$[0.596]$} & {$[0.009]^{* * *}$} & [0.892] & [0.942] \\
\hline & Pacific & -0.201 & -2.037 & -2.551 & -2.554 \\
\hline & & {$[0.862]$} & {$[0.061]^{*}$} & {$[0.000]^{* * *}$} & {$[0.007] * * *$} \\
\hline & European Union & 0.015 & -1.821 & -0.626 & -0.629 \\
\hline & & [0.944] & {$[0.000]^{* * *}$} & {$[0.027]^{* *}$} & [0.298] \\
\hline & $\begin{array}{l}\text { Average Developing } \\
\text { Country, non-ACP }\end{array}$ & -1.836 & & -0.003 & \\
\hline & & {$[0.005]^{* * *}$} & & [0.997] & \\
\hline & $(\operatorname{lnTF})^{2}$ & 0.248 & & 0.021 & \\
\hline & & {$[0.015]^{* *}$} & & {$[0.852]$} & \\
\hline
\end{tabular}

Note: Estimated regression coefficients for export transaction costs (TFE) and import transaction costs (TFI) from the baseline and extended models are displayed in columns 1 and 3. For the extended model, columns 2 and 4 show the sum of the reference group effect and the deviation, thus giving the full effect for each relevant group. Robust bootstrapped $p$-values in brackets. Asterisks denote significance at the $1 \%(* * *), 5 \%(* *)$ and $10 \%(*)$ levels.

elasticity of trade with respect to border delays is not constant: when the level of transaction costs is already high, waiting a little longer will be less harmful than at

\footnotetext{
${ }^{23}$ Since we use a Heckman procedure, the first stage probit estimation gives us some extra results concerning the impact of various variables on the likelihood that positive trade flows will occur between two countries. This paper focuses on the effect of trade transaction costs on trade volumes, so we will not have much to say about this issue, but the results are displayed in Table 8. For most variables, the effect on the likelihood of trade and on trade volumes goes in the same direction. In some specifications, we surprisingly get different signs for the import transaction costs variables in the first and second stage estimations. We do not have a good explanation for this. The positive, significant coefficients for the selection variable costs to start a business are perhaps not what one would expect, but it could be hypothesized that large costs to start a business will lead to few, but large companies, that in turn tend to export more than smaller ones, explaining why the country will have a positive, but possibly small, level of exports. Further, if there are few domestic companies, for consumption of many goods to be possible, the country will have to have some imports, even though again, the volume itself may be small.
} 
lower levels. ${ }^{23}$

Turning now to the extended model, it is important to note the different interpretation. Before the inclusion of interaction effects for EPA and EU countries, the coefficients for the main transaction cost variables for exports, TFE, and imports, TFI, gave the average effect of transaction costs for all countries. Now, they give the effect for the reference group not included in any interaction terms, i.e. developing, non-ACP countries.

Starting with column 1, the reference group of developing non-ACP countries has a negative and significant coefficient for export transaction costs. Apart from this, only the coefficients for West Africa, ESA and SADC are significant and negative. Thus, countries in these EPA groups have a significantly larger negative effect than the average non-ACP developing country.

To see the full effect for all groups, the relevant coefficients are added together in column 2. All coefficients are fairly large and have the expected negative sign, and are further significant for all groups but Central Africa. So for countries in West Africa, ESA, SADC, the Caribbean, the Pacific and the EU, export transaction costs have significantly negative effects on export flows. Further, the squared export transaction cost term has a positive and significant coefficient.

The results concerning import transaction costs are a bit more complicated. Looking at column three, in this case the reference group coefficient is not significantly different from zero; in fact, it is strikingly close to zero with a magnitude of -0.003 and a p-value of 0.997 . Also, in this case the squared import transaction cost variable is not significant. ${ }^{24}$ This means that the regression coefficients in column 3 really could be interpreted as the full import transaction cost effects, ${ }^{25}$ since they capture the deviation from the reference group, i.e. the deviation from zero. Noting that the coefficients for Western Africa, ESA, SADC, the Pacific and the EU are all negative and significant, one can therefore interpret this as saying that these groups, unlike the average non-ACP developing country, experience a significantly negative, but constant, elasticity of imports with respect to import transaction costs. For completeness, the relevant coefficients are also added together in column four, but we would argue that column three is the relevant one to study.

Having found evidence suggesting that delays at the border influence trade flows,

\footnotetext{
${ }^{24}$ The reason for this is presumably that by adding interaction effects for EPA groups, we control for a large part of the non-constant elasticity.

${ }^{25}$ I.e. elasticities.
} 
Table 4. Percentage Trade Effects of Reducing Exporting or Importing Time with One Day

\begin{tabular}{lcccccc}
\hline & \multicolumn{3}{c}{ Exporting } & \multicolumn{3}{c}{ Importing } \\
\hline Region & Mean-1 & Min-1 & Max-1 & Mean-1 & Min-1 & Max-1 \\
\hline West Africa & 2.6 & 6.9 & 1.1 & 1.1 & 2.3 & 0.7 \\
Central Africa & - & - & - & - & - & - \\
Eastern and Southern Africa & 0.9 & 7.1 & 0.3 & 1.0 & 4.5 & 0.6 \\
Southern Africa & 8.2 & 12.3 & 4.1 & 4.9 & 9.5 & 2.7 \\
Caribbean & 1.0 & 4.3 & 0.1 & - & - & - \\
Pacific & 3.9 & 8.7 & 1.2 & 15.1 & 40.6 & 8.4 \\
European Union & 4.9 & 74.7 & 0.6 & 4.3 & 15.0 & 1.9 \\
\hline
\end{tabular}

Note: Figures show the percentage effects on exports and imports from lowering the time needed at the border by one day from the mean number of days, the minimum number, and the maximum number. For the calculation, see footnote 26 . No figures are shown for country groups that do not have a significant coefficient in the regression.

an important policy question is how much trade flows would change for a given reduction of these border delays and the transaction costs they give rise to. Using coefficients from the baseline regression we find that, for the whole sample, lowering border delays from the mean by one day while holding all other variables constant would yield an export increasing effect of about 1 percent. The corresponding import trade facilitation would result in an import increase of about 0.5 percent. ${ }^{26}$

Table 4 contains some illustrative examples of how much EPA groups may gain by reducing waiting at the border by one day from various starting points. Our results suggest that exports from these country groups would rise by between 1 and 8 percent if waiting time at the border was reduced by one day from the mean. The largest effects are found for SADC, with over 8 percent extra exports. Effects are also sizeable for West Africa, ESA, the Caribbean and the Pacific with increases of $1-3.9$ percent. Noticeably, even though the coefficient itself was not very large for

\footnotetext{
${ }^{26}$ Since the model includes a squared transaction cost term, the formula used to calculate percentage import or export changes is $\Delta=\frac{\left(T F_{\text {New }}^{\delta(\phi)} * \exp \left(\theta\left(\ln T F_{\text {New }}\right)^{2}\right)-T F_{\text {lnitial }}^{\delta(\phi)} * \exp \left(\theta\left(\ln T F_{\text {Initial }}\right)^{2}\right)\right)}{T F_{\text {Intial }}^{\delta()} * \exp \left(\theta\left(\ln T F_{\text {Initial }}\right)^{2}\right)}$, where $\delta(\phi)$

refers to either the import (export) transaction cost coefficient from the baseline model without interactions, or, in the extended model, the sum of the reference group effect and the relevant EPA group deviation, and $\theta$ is the coefficient for the squared import or export transaction cost term. When calculating the effects from import transaction costs in the extended model, the expression simplifies since the coefficient $\theta_{2}$ is not significantly different from zero. In this case, we also choose to use the coefficients for the EPA or EU interaction terms directly, since the reference group effect is also nonsignificantly different from zero.
} 
the EU, thanks to the initially low level of transaction costs, a one-day reduction would give rise to an export increase of over 4 percent. This highlights the importance of taking the non-constant effect of trade facilitation into account. This is further illustrated in columns two and three, where it is evident that countries that already have small border delays would get larger effects from reducing them by one day.

Looking also at the potential effects from import trade facilitation in Table 4, West Africa, SADC and the EU see sizeable effects, but smaller than in the export case. The effect for ESA is about the same, but the main difference is that when looking at imports, we cannot find evidence of significant effects for Caribbean countries, while Pacific countries according to our results would get a very large effect. $^{27,28}$

To be able to say something more about the non-constant elasticity, we also perform a regression where the effects of export and import transaction costs are allowed to differ by time delay intervals, through the inclusion of interaction effects - results displayed in Table 5. These results offer further support for our conclusion that the elasticity of trade with respect to border delays decrease with increasing border delays. For both exports and imports, the regression coefficients show that the elasticity is negative for the reference group of countries having border delays ranging from 1 to 20 days, but, as illustrated by the positive coefficients for the interaction effects capturing the difference from the reference group, this elasticity is significantly less negative when border delays are larger. Summing the main and the interaction effects (giving the elasticities for the various delay ranges) shows that the elasticity, while always negative, becomes smaller and smaller in magnitude, and for export transaction costs we even cannot find a significant effect for countries with delays above 81 days. The columns showing the percentage trade effects of a one-day reduction also clearly illustrate that one finds the largest effects when waiting at the border is not too long to start with.

\footnotetext{
${ }^{27}$ Unlike the case of export transaction cost, the sample contains only observations from three Pacific countries - Papua New Guinea, Solomon Islands and Vanuatu - concerning import transaction costs. Hence, one should be cautious not to interpret these results too strongly.

${ }^{28}$ It should be kept in mind that these effects are calculated using the coefficients directly from the regression without adding the reference group effect. If one thinks it is more appropriate to use the coefficients with the insignificant reference group effect added, one should only look at the results for the SADC and the Pacific - for the other groups the very high p-value of the insignificant reference group coefficient decreases the significance of the summed coefficients.
} 
Table 5. Exploring the Non-Constant Elasticity

\begin{tabular}{ccccccc}
\hline \multicolumn{3}{c}{ Exporting: TFE } & \multicolumn{3}{c}{ Importing: TFI } \\
\hline $\begin{array}{c}\text { Delays } \\
\text { in Days }\end{array}$ & Regr. Coeff. & Sum TFE & Change & Regr. Coeff. & Sum TFI & Change \\
\hline $1-20$ & -0.755 & -0.755 & 8.3 & -0.721 & -0.721 & 7.9 \\
& {$[0.000]^{* * *}$} & {$[0.000]^{* * *}$} & & {$[0.000]^{* * *}$} & {$[0.000]^{* * *}$} & \\
$21-40$ & 0.039 & -0.716 & 2.5 & 0.065 & -0.656 & 2.2 \\
& {$[0.240]$} & {$[0.000]^{* * *}$} & & {$[0.173]$} & {$[0.000]^{* * *}$} & \\
$41-60$ & 0.128 & -0.627 & 1.3 & 0.197 & -0.524 & 1.1 \\
& {$[0.014]^{* *}$} & {$[0.000]^{* * *}$} & & {$[0.001]^{* * *}$} & {$[0.000]^{* * *}$} & \\
$61-80$ & 0.123 & -0.632 & 0.9 & 0.159 & -0.562 & 0.8 \\
& {$[0.102]$} & {$[0.000]^{* * *}$} & & {$[0.013]^{* * *}$} & {$[0.000]^{* * *}$} & \\
$81-100$ & 0.61 & -0.145 & 0.2 & 0.2 & -0.521 & 0.6 \\
& {$[0.000]^{* * *}$} & {$[0.289]$} & & {$[0.006]^{* * *}$} & {$[0.000]^{* * *}$} & \\
$101-120$ & & & & 0.284 & -0.437 & 0.4 \\
& & & & {$[0.060]^{*}$} & {$[0.010]^{* * *}$} & \\
$121-140$ & & & & 0.275 & -0.446 & 0.3 \\
& & & & {$[0.003]^{* * *}$} & {$[0.000]^{* * *}$} & \\
\hline
\end{tabular}

Note: Results from a Heckman regression where the effects of export and import transaction costs are allowed to differ by border delay intervals through the inclusion of interaction effects. The columns display the actual regression coefficients, the sum of the main and the interaction effects (i.e. the elasticities) and lastly the percentage export or import effect that would result from lowering the delays with one day from the middle of the interval: e.g. the effect of going from 10 to 9 days an so on. Robust bootstrapped $p$-values in brackets. Asterisks denote significance at the $1 \%(* *), 5 \%(* *)$ and $10 \%(*)$ levels.

\section{Robustness}

In the recent gravity literature, authors have tended to use either a sample selection approach or a Poisson Pseudo-Maximum-Likelihood (PPML) estimator. A sample selection approach have nice theoretical interpretations - see e.g. Helpman et al. (2007) for a discussion - while also solving the problem of zero trade flows, which is why we use it as our preferred strategy. However, Santos Silva and Tenreyro (2006) argue that the gravity equation should be estimated using a PPML estimator on its original multiplicative form. Unlike the traditional method of estimating the 
log-linearized equation with OLS, the PPML estimator is consistent even in the presence of heteroskedasticity and it will not ignore zero trade flows. So, on econometric grounds, the PPML estimator have some good properties. We therefore consider this to be our main alternative to the Heckman estimation, and use it to estimate both the baseline and extended models. ${ }^{29}$

Besides our two main alternatives, as further robustness checks we also use two extensions of the sample selection approach. Firstly, as noted by Djankov et al. (2006), endogeneity might be a concern, since trade volumes might affect waiting time at the border, for instance by causing congestion, and thus intensifying the problems with inefficient procedures. Using an ordinary Instrumental Variables (IV) estimation to solve this problem would not be appropriate, since one would then ignore the zeros, which is a problem considering that the inverse Mill's ratio in our Heckman estimation is indeed significant. Instead, to see whether taking endogeneity into account would affect our results, we estimate the baseline model with a procedure for sample selection with endogenous explanatory variables ${ }^{30}$ using the number of documents and signatures needed for exports and imports as instruments for the trade transaction variables. Finding valid instruments is always a challenge, but we would argue that these measures are not as likely to be influenced by trade flows (there is e.g. at least in the short run no reason to expect fewer or more documents to sign just because trade flows change), and at the same time, they are highly correlated with border delays, not least because delays partly arise due to excessive document or signature requirements. Secondly, we also follow Helpman et al. (2007), who suggest that when estimating the gravity equation, one should not only control for sample selection, which the ordinary Heckman procedure does, but also for the fraction of exporting firms. ${ }^{31}$

Adding more variables nearly always leads to a loss of observations so we choose to keep the model parsimonious, but as a further robustness check, we also estimate the model with various additional control variables. Along the lines of Wilson et al. (2005), we include measures for infrastructure, information technology and control

\footnotetext{
${ }^{29}$ Santos Silva and Tenreyro (2006) note that for the PPML estimator to be consistent, the data do not have to be Poisson distributed, and, in fact, the dependent variable does not even have to be an integer.

${ }^{30}$ Following Wooldridge (2002).

${ }^{31}$ We follow the empirical strategy in Helpman et al (2007), but for technical reasons, we do not estimate the second stage non-linear equation with maximum likelihood, but choose to use non-linear least squares - this strategy is in our case less time-consuming to implement.
} 
of corruption as broader aspects of trade facilitation. We also include the proportion of GDP coming from agriculture and the share of exports and imports from the US as ways to control for the content of trade.

For almost all the variables, the results remain very similar regardless of estimation method or specification. ${ }^{32}$ The most important exception is that we do not find a significant average effect from import transaction costs using the PPML estimator. All conclusions regarding import transaction costs in the EPA groups are exactly the same with this alternative estimator though. Some more discrepancies are that Central Africa does have a significant TFE coefficient with the PPML estimator, and that the squared transaction costs terms, even though always having the excepted signs, are slightly insignificant in the IV estimation and (on the import side) in the Poisson estimations.

In other words, in general, the results are not sensitive to the model being estimated with other methods designed specifically to solve various potential problems, or the inclusion of more control variables. All the same, one may probably be more confident in the results concerning export transaction costs, since these are really very robust, while the effects of import transaction costs are slightly more sensitive.

\section{Conclusions}

We have assessed how export and import transaction costs related to crossborder trade procedures affect trade flows on average. We have also estimated these effects separately for EPA negotiating groups and for the EU. Using data from the World Bank's (2007) Doing Business Database on the time required to export or import as indicators of trade transaction costs, we have estimated a gravity model on two-way bilateral trade between EU countries and developing countries using a sample selection approach.

We find that time delays both on the part of the exporter and the importer on average significantly decrease trade flows. This effect is, however, not constant: waiting a little longer has smaller marginal effects if the time requirements are already high. In other words, the elasticity of imports or exports with respect to border delays is negative, but declines at higher levels of waiting. On average, lowering border delays in the exporting country with one day (from the sample

$\overline{{ }^{32} \text { All results available upon request. }}$ 
mean) would yield an export increasing effect of about 1 percent, while the same reduction in the importing country would increase imports by about 0.5 percent. For most, though not all, EPA groups and the EU, we also find these negative and significant effects from export and import transaction costs, with the effects being at least as large as the average, or larger.

Concerning the average effects of trade facilitation, our results confirm the conclusions drawn by Djankov et al. (2006), Nordås et al. (2006) and Soloaga et al (2006) that export trade facilitation has positive potential effects, and these effects closely resemble in size those suggested by Djankov et al. (2006). Estimations of the potential effects of import trade facilitation have been rarer in the literature, but our results do confirm those obtained by Wilson et al. (2003; 2005). Our results highlight a number of issues though. Firstly, they illustrate the importance of including indicators for trade facilitation in both the exporting and the importing country: inefficient border procedures matter, regardless of where they occur. Secondly, our results clearly suggest that the effect of cumbersome border procedures is not linear, in the sense that the elasticity of exports or imports with respect to border delays declines at higher levels of waiting at the border, so a failure to take this into account can risk biasing one's results. This will be particularly important when analysing the policy implications of trade facilitation reforms. Thirdly, and related to this, it seems to be important to allow the effects of trade facilitation to differ for country groups. By just estimating one average effect and then using this to calculate the potential trade impact of reform, one will run a serious risk of drawing misleading conclusions.

To draw some policy conclusions, our results are certainly consistent with the hypothesis that making it simpler for goods to cross borders would have a positive effect on trade flows. This is particularly true for most EPA groups, for whom our results suggest trade increases even considerably larger than for the average country. These effects are not necessarily tied to the EPA framework, but it is important to note that by agreeing to facilitate trade in both the exporting and the importing country, one will get two positive effects on the same trade flow. Therefore, ACP countries, wanting for example to increase their exports, are likely to gain more from reaching a mutual agreement with the EU than through unilateral reform. This emphasizes the importance of including trade facilitation in any EPA agreement. However, even though our results concern trade between the EU and developing countries, naturally, reforms to make border procedures more efficient would likely affect trade with all other trading partners as well. 
Talking about policy implications, some caveats are in order though. Using a gravity model on cross-sectional data, one can establish correlation between trade flows and other variables, which is not the same as establishing causation. Further, there are sometimes large differences within EPA groups, meaning that an individual country's likely effects are not the same as the group average. Related to this, our results apply to total trade, but it is very likely that some goods are more timesensitive than other, so the effects for trade flows of specific goods might not be well described by our estimated elasticities. Therefore, policy makers should not take these figures too literally, but rather see our results as a complement to detailed case studies and results from other methodological approaches such as CGE studies.

\section{Acknowledgements}

The author is thankful for helpful comments and suggestions from Yves Bourdet, Joakim Gullstrand, Karin Olofsdotter, Therese Nilsson, Fredrik Bystedt and seminar participants at the European Trade Study Group (ETSG) Ninth Annual Conference; the Global Trade Analysis Project (GTAP) Tenth Annual Conference on Global Economic Analysis; The Nordic International Trade Seminars (NOITS) Tenth Annual Workshop and the Swedish Network for European Studies in Economics and Business (SNEE) Ninth Annual European Integration Conference. Financial support from Handelsbankens Forskningsstiftelser, Gyllenstiernska Krapperupsstiftelsen and Stiftelsen för Främjande av Ekonomisk Forskning vid Lunds Universitet is gratefully acknowledged.

Received 30 June 2007, Revised 7 March 2008, Accepted 8 April 2008 


\section{Appendix}

Table 6. Variables and Data Sources

\begin{tabular}{|c|c|}
\hline Imports & Imports for 2005 from the IMF (2006) Direction of Trade Statistics. \\
\hline GDP & World Bank (2006) World Development Indicators (WDI). \\
\hline Distance & Distance in kilometers between capital cities from CEPII (2006). \\
\hline Contiguity & Importer and exporter share a common border. From CEPII (2006). \\
\hline Common language & CEPII (2006). \\
\hline Colony & $\begin{array}{l}\text { Importer and exporter have been in a colonial relationship. From CEPII } \\
\text { (2006). }\end{array}$ \\
\hline Land area & World Bank (2006) WDI. \\
\hline Population & World Bank (2006) WDI. \\
\hline Landlocked & CEPII (2006). \\
\hline LDC & Country is a least developed country. \\
\hline Oil dummy & $\begin{array}{l}\text { Country is a major oil exporter according to the IMF's definition. See } \\
\text { IMF (2006) }\end{array}$ \\
\hline Average tariff & $\begin{array}{l}\text { Average applied tariff level, calculated using data at the HS2 level from } \\
\text { the MAcMap Database, CEPII (2007). See also Bouët et al (2004). }\end{array}$ \\
\hline Tariff dispersion & $\begin{array}{l}\text { A Herfindahl-type index is calculated using tariff data from CEPII } \\
\text { (2007). The index ranges from } 0 \text { to } 1 \text {, where a higher number is inter- } \\
\text { preted as more tariff peaks. Formula used: } h=\sum_{s}\left(\text { tariff }_{s} \wedge \sum_{s} \text { tariff }\right)^{2}\end{array}$ \\
\hline Trade facilitation & $\begin{array}{l}\text { See presentation in the text. Data from the World Bank (2007) Doing } \\
\text { Business Database downloaded February } 2007 .\end{array}$ \\
\hline $\begin{array}{l}\text { Procedures to start } \\
\text { a business }\end{array}$ & $\begin{array}{l}\text { The number of procedures needed to register a firm. Data from the } \\
\text { World Bank (2007) Doing Business Database. }\end{array}$ \\
\hline $\begin{array}{l}\text { Costs to start a } \\
\text { business }\end{array}$ & $\begin{array}{l}\text { The official cost in percent of per capita GNI of each procedure needed } \\
\text { to register a firm. Data from the World Bank (2007) Doing Business } \\
\text { Database. }\end{array}$ \\
\hline $\begin{array}{l}\text { Documents for } \\
\text { exports and } \\
\text { imports }\end{array}$ & $\begin{array}{l}\text { Data from the World Bank (2007) Doing Business Database down- } \\
\text { loaded February } 2007 \text {. }\end{array}$ \\
\hline Infrastructure & $\begin{array}{l}\text { Domestic and international takeoffs of air carriers registered in the } \\
\text { country. Data for } 2004 \text { from the World Bank (2006) WDI. }\end{array}$ \\
\hline $\begin{array}{l}\text { Information } \\
\text { Technology }\end{array}$ & $\begin{array}{l}\text { Internet users per } 1000 \text { people in } 2004 \text { from the World Bank (2006) } \\
\text { WDI. }\end{array}$ \\
\hline $\begin{array}{l}\text { Control of } \\
\text { Corruption }\end{array}$ & $\begin{array}{l}\text { Data from the Transparency International (2006) Corruption Percep- } \\
\text { tions Index. }\end{array}$ \\
\hline Share of agriculture & Agriculture's share of GDP in 2004 from the World Bank (2006) WDI. \\
\hline
\end{tabular}


Table 6. Variables and Data Sources

Trade pattern Share of exports to and imports from the US, from IMF (2006).

Note: All data are for 2005 unless otherwise stated.

Table 7. Sample of Developing Countries

\begin{tabular}{|c|c|}
\hline EPA Regions & \\
\hline West Africa & $\begin{array}{l}\text { Benin, Burkina Faso, Côte d'Ivoire, Ghana, Guinea*, Mali, Niger\#, } \\
\text { Nigeria, Senegal, Sierra Leone*, Togo }\end{array}$ \\
\hline Central Africa & $\begin{array}{l}\text { Cameroon, Central African Republic, Chad, Congo Dem. Rep. *, } \\
\text { Congo Rep., São Tomé and Principe* }\end{array}$ \\
\hline $\begin{array}{l}\text { Eastern and } \\
\text { Southern } \\
\text { Africa }\end{array}$ & $\begin{array}{l}\text { Burundi*, Eritrea*, Ethiopia, Kenya, Madagascar, Malawi, Mauritius, } \\
\text { Rwanda, Sudan, Uganda, Zambia, Zimbabwe }\end{array}$ \\
\hline SADC & $\begin{array}{l}\text { Angola*, Botswana*, Lesotho*, Mozambique, Namibia*, South Africa, } \\
\text { Tanzania }\end{array}$ \\
\hline Caribbean & Dominican Republic, Guyana, Haiti*, Jamaica \\
\hline Pacific & $\begin{array}{l}\text { Fiji*, Kiribati*, Palau*, Papua New Guinea, Samoa*, Solomon Islands, } \\
\text { Tonga*, Vanuatu }\end{array}$ \\
\hline \multicolumn{2}{|l|}{ Other Regions } \\
\hline South Asia & Bangladesh, Bhutan*, India, Maldives, Nepal, Pakistan, Sri Lanka \\
\hline South-East Asia & Cambodia, Indonesia, Lao PDR, Malaysia, Philippines, Thailand, Vietnam \\
\hline $\begin{array}{l}\text { Eastern Europe and } \\
\text { Central Asia }\end{array}$ & $\begin{array}{l}\text { Armenia, Azerbaijan, Belarus, Georgia, Kazakhstan, Kyrgyz Republic\#, } \\
\text { Moldova, Russian } \\
\text { Federation, Ukraine, Uzbekistan }\end{array}$ \\
\hline Middle East & Iran, Kuwait, Saudi Arabia, Yemen \\
\hline Mercosur & Argentina, Brazil, Paraguay, Uruguay \\
\hline Mediterranean & Algeria, Egypt, Jordan, Lebanon, Morocco, Syrian Arab Republic, Tunisia \\
\hline Drug & $\begin{array}{l}\text { Bolivia, Colombia, Costa Rica, Ecuador, El Salvador, Guatemala, } \\
\text { Honduras, Nicaragua, Panama, Peru, Venezuela }\end{array}$ \\
\hline Other & China, Mongolia* \\
\hline
\end{tabular}


Table 8. Estimation Results

\begin{tabular}{|c|c|c|c|c|}
\hline \multirow{2}{*}{ Variable } & \multicolumn{2}{|c|}{ Baseline } & \multicolumn{2}{|c|}{ Extended } \\
\hline & Heckman & 1st step Probit & Heckman & 1st step Probit \\
\hline \multirow{2}{*}{ yy } & 1.059 & 0.651 & 1.067 & 0.648 \\
\hline & {$[0.000] * * *$} & {$[0.000]^{* * *}$} & {$[0.000]^{* * *}$} & {$[0.000] * * *$} \\
\hline \multirow[t]{2}{*}{ Dist } & -1.301 & -0.566 & -1.424 & -0.627 \\
\hline & {$[0.000] * * *$} & {$[0.041]^{* *}$} & {$[0.000]^{* * *}$} & {$[0.142]$} \\
\hline \multirow[t]{2}{*}{ Area exp } & 0.188 & -0.053 & 0.177 & -0.075 \\
\hline & {$[0.000]^{* * *}$} & [0.501] & {$[0.004]^{* * *}$} & [0.340] \\
\hline \multirow[t]{2}{*}{ Area exp_eu } & -0.311 & 0.673 & -0.319 & 0.743 \\
\hline & {$[0.000] * * *$} & {$[0.007] * * *$} & {$[0.000]^{* * *}$} & {$[0.031]^{* *}$} \\
\hline \multirow[t]{2}{*}{ Area imp } & -0.051 & -0.074 & -0.028 & -0.082 \\
\hline & [0.164] & {$[0.554]$} & {$[0.461]$} & [0.582] \\
\hline \multirow[t]{2}{*}{ Area imp_eu } & -0.811 & -0.08 & -0.813 & -0.082 \\
\hline & {$[0.000]^{* * *}$} & {$[0.717]$} & {$[0.000]^{* * *}$} & [0.686] \\
\hline \multirow[t]{2}{*}{ Pop exp } & -0.08 & 0.044 & -0.04 & 0.069 \\
\hline & [0.204] & {$[0.722]$} & {$[0.530]$} & [0.598] \\
\hline \multirow[t]{2}{*}{ Pop exp_eu } & 0.335 & -0.323 & 0.275 & -0.397 \\
\hline & {$[0.000] * * *$} & [0.118] & {$[0.000]^{* * *}$} & [0.285] \\
\hline \multirow[t]{2}{*}{ Pop imp } & -0.045 & -0.26 & -0.079 & -0.284 \\
\hline & {$[0.440]$} & {$[0.093]^{*}$} & [0.272] & {$[0.191]$} \\
\hline \multirow[t]{2}{*}{ Pop imp_eu } & 0.806 & 0.423 & 0.849 & 0.47 \\
\hline & {$[0.000]^{* * *}$} & {$[0.039]^{* *}$} & {$[0.000]^{* * *}$} & {$[0.030]^{* *}$} \\
\hline \multirow[t]{2}{*}{ Contiguity } & 0.754 & 2.794 & 0.68 & 2.634 \\
\hline & {$[0.012]^{* *}$} & {$[0.068]^{*}$} & {$[0.023]^{* *}$} & {$[0.080]^{*}$} \\
\hline \multirow[t]{2}{*}{ Common language } & 0.698 & 0.077 & 0.668 & 0.094 \\
\hline & {$[0.000] * * *$} & {$[0.924]$} & {$[0.000]^{* * *}$} & {$[0.936]$} \\
\hline \multirow[t]{2}{*}{ Colony } & 0.69 & 0.022 & 0.696 & 0.102 \\
\hline & {$[0.000] * * *$} & [0.993] & {$[0.000]^{* * *}$} & [0.968] \\
\hline \multirow[t]{2}{*}{ Landlocked exp } & -0.724 & -0.293 & -0.637 & -0.418 \\
\hline & {$[0.000] * * *$} & {$[0.205]$} & {$[0.004]^{* * *}$} & [0.119] \\
\hline \multirow[t]{2}{*}{ Landlocked exp_EU } & 0.982 & 0.157 & 0.853 & 0.266 \\
\hline & {$[0.000] * * *$} & {$[0.581]$} & {$[0.000]^{* * *}$} & {$[0.494]$} \\
\hline \multirow[t]{2}{*}{ Landlocked imp } & -0.434 & 0.691 & -0.44 & 0.656 \\
\hline & {$[0.000] * * *$} & {$[0.010]^{* *}$} & {$[0.000]^{* * *}$} & {$[0.022]^{* *}$} \\
\hline \multirow[t]{2}{*}{ Landlocked imp_eu } & -0.236 & -0.545 & -0.207 & -0.522 \\
\hline & [0.199] & {$[0.100]$} & {$[0.229]$} & {$[0.136]$} \\
\hline \multirow[t]{2}{*}{ LDC exp } & -1.125 & -0.523 & -1.037 & -0.532 \\
\hline & {$[0.000] * * *$} & {$[0.018]^{* *}$} & {$[0.000]^{* * *}$} & {$[0.039]^{* *}$} \\
\hline
\end{tabular}


Table 8. Estimation Results

\begin{tabular}{|c|c|c|c|c|}
\hline LDC imp & $\begin{array}{c}-0.435 \\
{[0.000]^{* * *}} \\
-0.98 \\
{[0.001]^{* * *}}\end{array}$ & $\begin{array}{c}-0.059 \\
{[0.838]} \\
-1.276 \\
{[0.184]}\end{array}$ & $\begin{array}{c}-0.535 \\
{[0.000]^{* * *}} \\
-0.964 \\
{[0.001]^{* * *}}\end{array}$ & $\begin{array}{c}-0.03 \\
{[0.934]} \\
-1.196 \\
{[0.231]}\end{array}$ \\
\hline \multicolumn{5}{|l|}{ Table 8. Continued } \\
\hline \multirow{2}{*}{ Variable } & \multicolumn{2}{|c|}{ Baseline } & \multicolumn{2}{|c|}{ Extended } \\
\hline & Heckman & 1st step Probit & Heckman & 1st step Probit \\
\hline \multirow[t]{2}{*}{ Oil imp } & -0.534 & 5.549 & -0.582 & 5.384 \\
\hline & {$[0.001]^{* * *}$} & {$[0.000]^{* * *}$} & {$[0.000]^{* * *}$} & {$[0.000]^{* * *}$} \\
\hline \multirow[t]{2}{*}{ Average tariff Dev } & -0.191 & -0.755 & -0.288 & -0.626 \\
\hline & {$[0.035]^{* *}$} & {$[0.008]^{* * *}$} & {$[0.003]^{* * *}$} & {$[0.048] * *$} \\
\hline \multirow[t]{2}{*}{ Tariff dispersion Dev } & -0.325 & 0.025 & -0.263 & -0.053 \\
\hline & {$[0.000]^{* * *}$} & [0.893] & {$[0.003]^{* * *}$} & {$[0.805]$} \\
\hline \multirow[t]{2}{*}{ Trade Facilitation Exp (TFE) } & -1.506 & -0.298 & -1.836 & -1.045 \\
\hline & {$[0.000]^{* * *}$} & {$[0.498]$} & {$[0.005]^{* * *}$} & {$[0.440]$} \\
\hline \multirow[t]{2}{*}{ Trade Facilitation Imp (TFI) } & -1.267 & 1.449 & -0.003 & 1.174 \\
\hline & {$[0.002]^{* * *}$} & {$[0.050]^{* *}$} & [0.997] & {$[0.544]$} \\
\hline \multirow[t]{2}{*}{ TFE2 } & 0.174 & 0.028 & 0.248 & 0.138 \\
\hline & {$[0.021]^{* *}$} & {$[0.722]$} & {$[0.015]^{* *}$} & {$[0.482]$} \\
\hline \multirow[t]{2}{*}{ TFI2 } & 0.147 & -0.33 & 0.021 & -0.267 \\
\hline & {$[0.024]^{* *}$} & {$[0.013]^{* *}$} & {$[0.852]$} & {$[0.311]$} \\
\hline \multirow[t]{2}{*}{ TFE EU } & & & 0.015 & 0.301 \\
\hline & & & [0.944] & {$[0.640]$} \\
\hline \multirow[t]{2}{*}{ TFE West Africa } & & & -1.029 & 0.812 \\
\hline & & & {$[0.036]^{* *}$} & {$[0.148]$} \\
\hline \multirow[t]{2}{*}{ TFE Central Africa } & & & -0.026 & 1.082 \\
\hline & & & {$[0.982]$} & {$[0.482]$} \\
\hline \multirow[t]{2}{*}{ TFE Eastern and Southern Africa } & & & -0.582 & -0.95 \\
\hline & & & {$[0.070]^{*}$} & {$[0.142]$} \\
\hline \multirow[t]{2}{*}{ TFE SADC } & & & -3.253 & -2.424 \\
\hline & & & {$[0.071]^{*}$} & {$[0.082]^{*}$} \\
\hline \multirow[t]{2}{*}{ TFE Caribbean } & & & -0.245 & 0.048 \\
\hline & & & {$[0.596]$} & {$[0.975]$} \\
\hline \multirow[t]{2}{*}{ TFE Pacific } & & & -0.201 & 0.157 \\
\hline & & & {$[0.862]$} & {$[0.833]$} \\
\hline \multirow[t]{2}{*}{ TFI EU } & & & -0.626 & -0.03 \\
\hline & & & {$[0.027]^{* *}$} & [0.974] \\
\hline \multirow[t]{2}{*}{ TFI West Africa } & & & -0.583 & 0.172 \\
\hline & & & {$[0.096]^{*}$} & [0.839] \\
\hline \multirow[t]{2}{*}{ TFI Central Africa } & & & 0.254 & -0.729 \\
\hline & & & {$[0.762]$} & {$[0.814]$} \\
\hline TFI Eastern and Southern Africa & & & -0.68 & -1.563 \\
\hline
\end{tabular}


Table 8. Continued

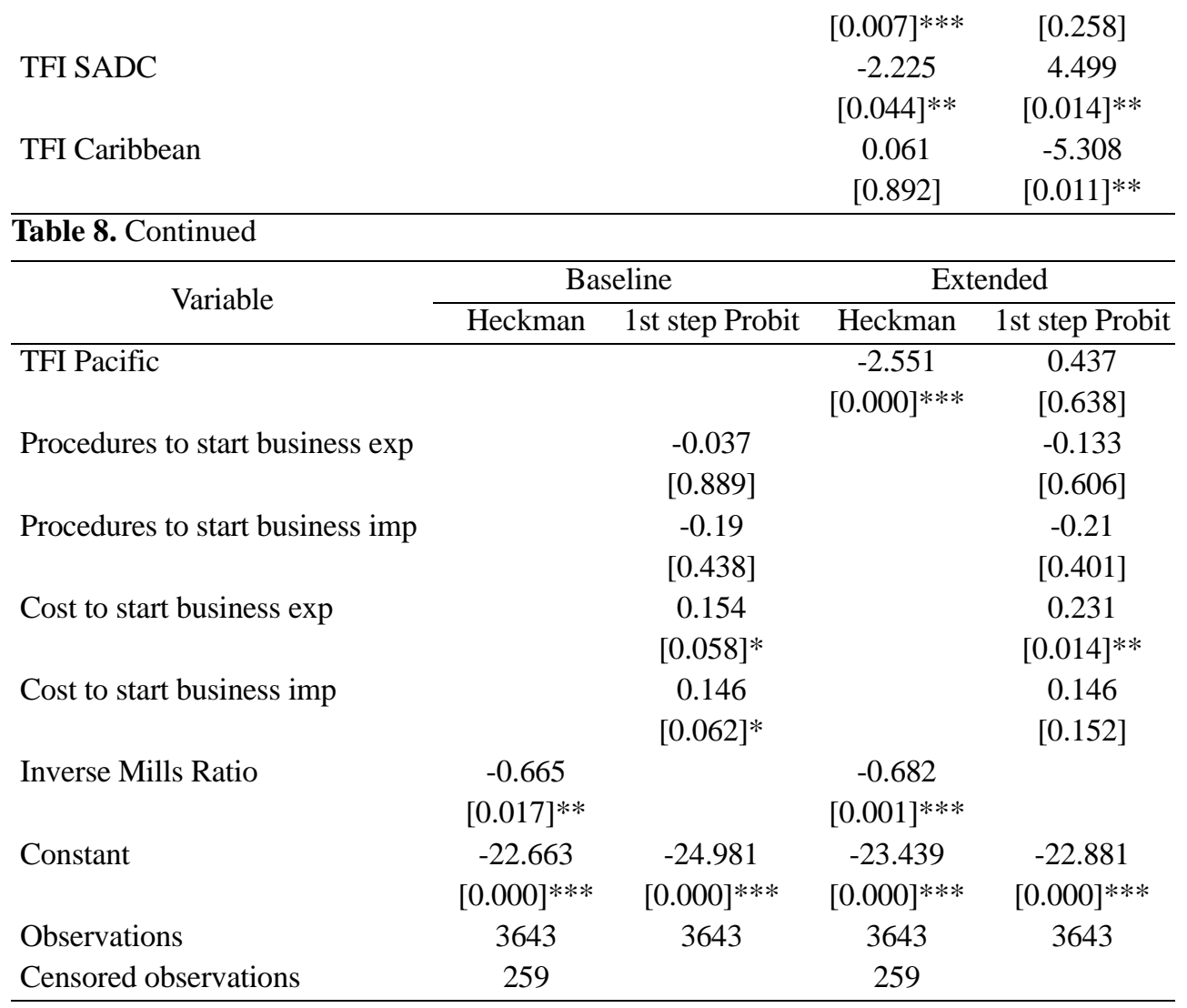

Note: Robust bootstrapped $p$-values in brackets. Asterisks denote significance at the $1 \%(* * *), 5 \%(* *)$ and $10 \%(*)$ levels.

\section{References}

ACP Council of Ministers (2002), "ACP Guidelines for the Negotiations of Economic Partnership Agreements", ACP/61/056/02 [FINAL].

Anderson, James E. (1979), "A Theoretical Foundation for the Gravity Equation", American Economic Review, Vol. 69, No. 1, pp. 106-116.

Anderson, James E. and Eric van Wincoop (2003), "Gravity with Gravitas: A Solution to the Border Puzzle", American Economic Review, Vol. 93, No. 1, pp. 170-192.

Anderson, James E. and Eric van Wincoop (2004), "Trade Costs", Journal of Economic Literature, Vol. 42, No. 3, pp. 691-751.

Bergstrand, Jeffrey H (1985), "The Gravity Equation in International Trade: Some Microeconomic Foundations and Empirical Evidence", Review of Economics and Statistics, Vol. 67, No. 3, pp. 474-481.

Bergstrand, Jeffrey H. (1989), "The Generalized Gravity Equation, Monopolistic 
Competition, and the Factor-Proportions Theory in International Trade", Review of Economics and Statistics, Vol. 71, No. 1, pp. 143-153.

Bouët, Antoine, Yvan Decreux, Lionel Fontagné, Sébastien Jean and David Laborde (2004), "A Consistent, Ad-Valorem Equivalent Measure of Applied Protection Across the World : The MAcMap-HS6 Database", CEPII Working Paper No. 200422.

CEPII (2006), "Distances", http://www.cepii.fr/anglaisgraph/bdd/distances.htm.

CEPII (2007), "HS2 Aggregation: Applied rates from MAcMap HS6 v1.1 and Bound Tariffs", http://www.cepii.fr/anglaisgraph/bdd/macmap/form_macpmap/download.asp.

Deardorff, Alan V. (1998), "Determinants of Bilateral Trade: Does Gravity Work in a Neoclassical World", in J. A. Frankel (ed.), The Regionalization of the World Economy. Chicago: University of Chicago Press, pp. 7-22.

Decreux, Yvan and Lionel Fontagné (2006), "A Quantitative Assessment of the Outcome of the Doha Development Agenda", CEPII Working Paper No. 2006-10.

Dennis, Allen (2006), "The Impact of Regional Trade Agreements and Trade Facilitation in the Middle East North Africa Region", World Bank Policy Research Working Paper No. 3837.

Djankov, Simeon, Caroline Freund and Cong S. Pham (2006), "Trading on Time”, World Bank Policy Research Working Paper No. 3909.

ECDPM (2006), "Overview of the Regional EPA Negotiations: West Africa-EU Economic Partnership Agreement", ECDPM InBrief 14B, Maastricht: www.ecdpm.org/inbrief14b.

Engman, Michael (2005), "The Economic Impact of Trade Facilitation", OECD Trade Policy Working Paper No. 21.

European Commission (2002), "Explanatory Memorandum. Commission Draft Mandate 9 April 2002", http://trade.ec.europa.eu/doclib/docs/2006/september/tradoc_112023.pdf.

European Commission (2006), http://ec.europa.eu/comm/external_relations/.

European Commission (2007a), "Economic Partnership Agreements (EPAs). Negotiations: A New Approach to ACP-EU Trade Cooperation", http://ec.europa.eu/trade/issues/bilateral/ regions/acp/epas.htm.

European Commission (2007b), "The EU Welcomes South Africa in the SADC EPA negotiation", http://ec.europa.eu/trade/issues/bilateral/countries/southafrica/pr140207_en.htm

Francois, Joseph, Hans van Meijl and Frank van Tongeren (2005), "Trade Liberalization in the Doha Development Round", Economic Policy, Vol. 20, No. 42, pp. 349-391.

Helpman, Elhanan and Paul R. Krugman (1985), Market Structure and Foreign Trade, Cambridge, Mass.: MIT Press.

Helpman, Elhanan, Marc J. Melitz and Yona Rubinstein (2007), "Estimating Trade Flows: Trading Partners and Trading Volumes", NBER Working Paper No. 12927.

Hertel, Thomas W. and Roman Keeney (2006), "What is at Stake: The Relative Importance of Import Barriers, Export Subsidies, and Domestic Support", in Kym Anderson and Will Martin (eds.), Agricultural Trade Reform \& the Doha Development Agenda, Washington D.C.: The World Bank and Hampshire and New York: Palgrave Macmillan, pp. 37-62. 
Hummels, David (2001), "Time as a Trade Barrier", mimeo, Purdue University. IMF (2006), Direction of Trade Statistics. CD-ROM.

Melitz, Marc J. (2003), "The Impact of Trade on Intra-Industry Reallocations and Aggregate Industry Productivity", Econometrica, Vol 71, No. 6, pp. 1695-1725.

Nath, Kamal and Peter Mandelson (2006), "Doha Round: It's not only what we trade, but how", International Herald Tribune, July 5, 2006.

Nordås, Hildegunn Kyvik, Enrico Pinali and Massimo Geloso Grosso (2006), "Logistics and Time as a Trade Barrier", OECD Trade Policy Working Paper No. 35.

Nyamache, Nyachienga (2006), "Trade Facilitation”, EU-ACP Negotiations in Focus, Project Management Unit, http://www.euacpepa.org:8080/index.php?page=43\&lg=en.

OECD (2003), "Quantitative Assessment of the Benefits of Trade Facilitation", TD/TC/ WP(2003)31/FINAL

Persson, Maria and Fredrik Wilhelmsson (2007), "Assessing the Effects of EU Trade Preferences for Developing Countries", in Yves Bourdet, Joakim Gullstrand and Karin Olofsdotter (eds.): The European Union and Developing Countries: Trade, Aid and Growth in an Integrating World. Cheltenham and Northampton: Edward Elgar, pp. 29-48.

Roy, Jayanta and Shweta Bagai (2005), "Key Issues in Trade Facilitation. Summary of World Bank/EU Workshops in Dhaka and Shanghai in 2004", World Bank Policy Research Working Paper No. 3703.

Santos Silva, João M. C. and Silvana Tenreyro (2006), "The Log of Gravity”, Review of Economics and Statistics, Vol. 88, No. 4, pp. 641-658.

Soloaga, Isidro, John S. Wilson and Alejandro Mejía (2006), "Moving Forward Faster: Trade Facilitation Reform and Mexican Competitiveness", World Bank Policy Research Working Paper No. 3953.

Swedish National Board of Trade (2006), Economic Implications of the Doha Round, Stockholm.

Transparency International (2006), Corruption Perceptions Index, http://www.icgg.org/ corruption.cpi_2006.html.

Wilson, John S., Catherine L. Mann and Tsunehiro Otsuki (2003), "Trade Facilitation and Economic Development: A New Approach to Quantifying the Impact", World Bank Economic Review, Vol. 17, No. 3, pp. 367-389.

Wilson, John S., Catherine L. Mann and Tsunehiro Otsuki (2005), "Assessing the Benefits of Trade Facilitation: A Global Perspective", World Economy, Vol. 28, No. 6, pp. $841-71$.

Wooldridge, Jeffrey M. (2002), Econometric Analysis of Cross Section and Panel Data, Cambridge, Mass. MIT Press.

World Bank (2006), World Development Indicators Online.

World Bank (2007), Doing Business Database, http://www.doingbusiness.org/ExploreTopics/ TradingAcrossBorders/.

WTO (2001) Ministerial Conference, Fourth Session, Doha, 9-14 November 2001, "Ministerial Declaration", WT/MIN(01)/DEC/1, 20 November. 